\title{
The Arab Spring or How to Explain those Revolutionary Episodes?
}

\author{
Cédric Dupont and Florence Passy \\ Graduate Institute of International and Development Studies, Geneva and University of \\ Lausanne
}

The Arab Spring began in Tunisia with the dramatic suicide of Mohamed Bouazizi in December 2010. Bouazizi was a street peddler whose produce was arbitrarily confiscated by a police officer. In reaction to that measure, and also probably in reaction to the poor living conditions forcing educated young people to sell fruit in the street to survive in Ben Ali's Tunisia, Bouazizi committed suicide in the public arena. In the days following this dramatic event protestors invaded central squares in most Tunisian cities. The protest rapidly spread throughout the country mobilizing millions of people until Ben Ali fled into exile on January 14 , ending twenty-three years in power. The story could have ended there but did not. On January 25, protestors took to the streets in Cairo to push Mubarak out of power and sustained action for eighteen days, despite violent repression. They resisted police violence and their own fear, and progressively crowded into Tahrir Square. On February 11, Mubarak stepped down and turned power over to the army. Waves of protest continued to develop throughout the Middle East. After Tunisia and Egypt, protest emerged in Bahrain, Algeria, Libya and then Morocco, Yemen, Jordan, Syria as well as Lebanon, Oman and Saudi Arabia. Protest is still in motion in most of these countries.

The events of the Arab Spring caught most experts and analysts by surprise, including social movements scholars. They seemed to be unpredictable protest events. The surge of sudden protest seemed to follow a diffusion process touching almost all the countries in the region. In addition, this succession of unpredictable revolutionary episodes took place in what Migdal (1988) would label "strong states and weak societies". These contentious processes occurred in some of the most authoritarian regimes in the world in terms of repression and social control over the population. Protestors also came from weak civil societies. As in most authoritarian regimes, civil societies were apparently unorganized and certainly highly repressed. Moreover, Middle Eastern societies in which protestors had previously voiced their grievances were highly fragmented with multiple salient cleavages. Finally, authoritarian regimes in the region had benefited from strong political as well as economic and military support from important international political allies, such as the United-States, some European countries, Russia, and China. In this particular social and political context how can we explain the sudden surge in persistent and stiff resistance and demonstrations?

\section{Challenging Questions for Social Movements Scholars?}

How can we make sense of the protest and revolutionary processes that seemed unlikely to occur within these strong states and weak societies? The question is twofold. First, how do we explain these events with current knowledge on protest politics? Social movements scholars have developed three main theoretical avenues to understand protest: political opportunity theory, which emphasizes the importance of political factors that constrain or facilitate the emergence and the development of protest; the resource mobilization approach stressing the importance of the organization of protest, in particular through networks and ties between segments of the population; and finally framing theory, which states the necessity of a cognitive revolution or consciousness transformation to turn mere grievances into protest and 
claim-making. Do these theoretical avenues provide social movements scholars with strong analytical tools in order to explain how and why people took to the streets to overthrow authoritarian regimes? In other terms, with the help of our current knowledge are social movements scholars able to make sense of the Arab Spring?

Second, do these events challenge our current theoretical models and force us to revise our existing theoretical frameworks? If so, to what extent and on what specific points? The events of the Arab Spring invite scholars to test, and maybe revise a theoretical corpus that has been mainly developed for cases in the Western world, although some work on other societies has emerged over the last decade - for instance on Latin America (e.g. Schneider 1995, Wood 2003), on Iran (Kurzman 2004), and on China (e.g. Calhoun 1997, Perry 2001). The Arab Spring is formidable terrain to improve our knowledge as it adds new social and political contexts for studying protest politics. Furthermore, the Arab Spring seems to be specific at least on one dimension: the diffusion of protest across state borders. In the history of protest politics, contentious contagions are not new phenomena - the student revolts in the 1960s or the Velvet Revolutions in Eastern Europe are illustrative. However we still have a limited understanding of such protest waves, and diffusion effects are still understudied and insufficiently theorized. The Arab Spring offers us fertile research terrain from which to address these gaps.

\section{Specific Questions for Social Movements Scholars}

The series of rapidly growing and diffusing protests in the Arab world raises a large set of questions for social and political scientists. First of all, given the widespread sense of surprise among analysts and observers, were these protests actually unpredictable events? Were they unpredictable because our lack of knowledge and information on these authoritarian and closed regimes led experts to believe that the Arab Spring was unthinkable? A similar situation occurred when Eastern Europe began to get rid of its dictatorships. Many analysts were surprised to see street demonstrations in East Germany mobilizing an increasingly angered population day after day. After the regime collapsed, scholars who studied this revolutionary outcome highlighted the existence of dense underground networks of dissidents, divided ruling elites, the absence of a Soviet threat in case of riots and regime collapse, and other key factors helping social movements scholars explain the East German revolutionary process and outcome post hoc. Are we in similar situation with the Arab uprisings? Social scientists are not strong in predicting the occurrence and timing of social phenomena such as protest, yet have been able to identify potentially revolutionary contexts when they have enough information available. Is it the case that the events of the Arab Spring were really unpredictable because elements usually associated with revolutionary processes (pre-existing networks, power fragmentation, cross-class coalitions, etc.) were not present in the Arab uprisings?

Second, are they sudden and spontaneous protests? Social movements scholars tell us that no protest emerges spontaneously and without deep organizational roots. But what was the situation in those countries where civil societies were rather weak and undeveloped? Did preexisting contentious networks exist before people took to the streets? What were these networks? How did distinct networks join together to bring down discredited regimes? For example, how could Islamist networks collaborate with secular groups to oust Ben Ali, Mubarak or Gaddafi? How did groups of people motivated by different values and defending often-contradictory goals bind together, and in some countries in such a short period of time? Did internet and computer technology facilitate linkages between separate groups of the 
population? Did social media constitute a key factor enabling the Arab uprisings or did it merely play a facilitating role (by more quickly circulating information; by reducing state repression in organizing protest coalitions; etc.), or still, did it play no role at all? Was international support of dissidents in exile an important element in organizing protest under authoritarian states? For example, in early October 2011 the Syrian opposition formed a National Council gathering all societal forces opposed to the merciless Hafez el-Assad's regime. Half of the council is composed of dissidents living outside Syria.

Third, did cognitive liberation emerge in the mind of oppressed populations, and could it explain why the Arab Spring took off? Framing theory makes us aware that a process of deep transformation of people's consciousness is a necessary condition for protest. Studying poor people's movements in the United-States, Piven and Cloward (1979: 3) argued: "The emergence of protest entails a transformation of both consciousness and behavior." People need to develop a frame of indignation, a shared perceived identity with contenders as well as the sentiment that they could bring about social and political changes. Many grievances were out there: poor living conditions, high levels of unemployment, police brutality, limited freedom of speech, state arbitrariness, etc. But how have these cognitive frames of action developed in those populations oppressed by authoritarian regimes? Did people suddenly withdraw legitimacy from their authorities once the first events took place? Or were delegitimation and injustice frames already present? How could people belonging to separate segments of society create a we-group as protestors and develop a common identity as contenders? How could workers, students, secular democrats, human rights defenders, lawyers, and Islamic protestors claim all together in Tahrir Square "WE want Mubarak out"? Finally, how did people suddenly decide to take on the street to usher illegitimated presidents? What did make them feel that they could now change the world out there and become agents of their own history?

Fourth, people make their own history, as Karl Marx taught us a century ago, but under heavy constraints. Political opportunity theory highlights the importance of carefully examining the state and the ruling elites that are challenged. The Arab spring protests have faced authoritarian regimes unresponsive to the claims of their population and possessing high levels of control and repressive power. In addition, most of these dictatorships had long benefited from strong support from international political allies. How could people engage in protest politics with such political constraints? Why did protestors risk torture and death to fight a regime they had so little chance of overthrowing? Did a window of opportunity open up that could be seized by aggrieved populations? Did ruling elites play a crucial role in opening up this window of opportunity? Were ruling elites divided and split into rival factions as was the case in communist East Germany? For example, Tunisia, Egypt and Libya were initiating power transition processes. Relatives of the strong men in power had been groomed for succession: Sakhr Matri who is Ben Ali's son-in-law, Gamal the younger of Mubarak's two sons, and Seif al-Islam one of Gadaffi's sons. Did these succession plans fissure the unity of powerholders and open up a breach for contenders? And what was the role of the army in these authoritarian countries? Were armies also divided and prone to withdraw their loyalty to the strong man in power? Finally, how does the international structure of political alliances support or hinder the ability of protesters to contest discredited states?

The aforementioned questions are tightly connected to the existing body of theories on social movements (political opportunity theory, the resource mobilization approach and framing theory). We would like to add two additional questions that invite scholars to expand their 
existing heuristic frameworks. First, the Arab Spring seems to be a succession of events that spread like wildfire across the whole Middle East. Are these events linked to each other, either objectively or subjectively through actors' minds? Did revolutionary episodes follow patterns of diffusion, and if this is the case what are the channels of this diffusion: networks and ties binding protestors across countries, traditional media such as Al Jazira, social and virtual networks such as Facebook or Twitter, or still other channels allowing for the spread of protest throughout the region? And what was diffused: action strategies, tactics to avoid repression, organizational models, symbolic action frames, or still other elements?

Second, the Middle East region was, and still is, the scene of amazing protest and revolutionary processes. However there is obvious variation among these processes. Some revolutionary processes took place almost peacefully (e.g. Tunisia and Egypt), while others face harsh state resistance and violence, thus paralleling civil wars (e.g. Libya and increasingly Syria). Outcomes of the processes have differed too: in some countries regimes collapsed (e.g. Libya and Tunisia), while in others power holders have been challenged but have remained in power (e.g. Morocco and Bahrain). Some protest movements led to quick power changes (e.g. Tunisia and Egypt), while others have prompted longer processes (e.g. Syria and Yemen). The metaphor of the Arab Spring may give the false impression that highly distinct protests and revolutionary protests are homogeneous. Making sense of both commonalities and variation is the challenge of future work for scholars.

\section{A Short Debate but Long Lasting Discussions}

We invited outstanding social movements scholars to offer us some insights on the main sets of questions discussed above. Of course, the seven contributions in this debate on the Arab Spring do not exhaustively cover all these questions. They bring some insightful views on the difficulty to formulate theories of such events (Goodwin) on the importance of cross-class coalitions (Goldstone), on collective action frames (Gamson), on the role of the internet for networks (Diani), on political opportunity structures (Alimi and Meyer), on violence and state repression (Schneider) and on the role of the military (Nepstad). We would like to deeply thank all these authors for participating in this debate. Writing a contribution to such a symposium is not an easy task for two main reasons. First, protest events and revolutionary episodes in the Middle East are still in motion. Second, systematic data has not yet been collected and little valid information is at the disposal of researchers. Both constraints make the exercise risky.

This debate focuses merely on understanding the recent revolutionary episodes in the Arab world, and on how these episodes challenge our current theoretical models. The final outcome of these processes is very much uncertain, as are their consequences at both the national and international levels. At the national level we can expect probable state transformation in certain countries or reforms for others, and at the international and regional level we can anticipate, among other things, a redistribution of power alignments that may have an impact on regional stability. We asked a second series of scholars to offer their views on the repercussions of protest movements and we will publish their contributions in the next, or next but one, issue of the SPSR.

\section{References}


Calhoun, C. J. (1997). Neither Gods nor Emperors. Students and the Struggle for Democracy in China. Los Angeles : University of California Press.

Kurzman, C. (2004). The Unthikable Revolution in Iran. Harvard: Harvard University Press.

Migdal, J. S. (1988). Strong Societies and Weak States: State-Society Relations and State Capabilities in the Third World. Princeton: Princeton University Press

Perry, E. J. (2001). Challenging the Mandate of Heaven. Social Protest and State Power in China (Asia and Pacific). New York : Sharpe.

Piven, F. F. and R. A. Cloward. (1977). Poor People's Movements. Why they Succeed, How they Failed. New York: Vintage Books.

Schneider, C. L. (1995). Shantytown Protest in Pinochet's Chile. Philadelphia: Temple University Press.

Wood, E. J. (2003). Insurgent Collective Action and Civil War in El Salvador. Cambridge: Cambridge University Press. 